Revue d'études américaines. American Studies Journal

$2 \mid 2017$

(Hi)stories of American Women: Writings and Rewritings / Call and Answer: Dialoguing the American West in France

\title{
Gauguin, Buffalo Bill, and the Cowboy Hat
}

\section{Nancy Mowll Mathews}

\section{(2) OpenEdition}

\section{Journals}

Electronic version

URL: https://journals.openedition.org/transatlantica/10968

DOI: 10.4000/transatlantica.10968

ISSN: $1765-2766$

Publisher

Association française d'Etudes Américaines (AFEA)

Electronic reference

Nancy Mowll Mathews, "Gauguin, Buffalo Bill, and the Cowboy Hat", Transatlantica [Online], 2 | 2017, Online since 13 May 2019, connection on 31 January 2023. URL: http://journals.openedition.org/ transatlantica/10968; DOI: https://doi.org/10.4000/transatlantica.10968

This text was automatically generated on 31 January 2023.

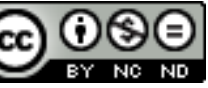

Creative Commons - Attribution-NonCommercial-NoDerivatives 4.0 International - CC BY-NC-ND 4.0 https://creativecommons.org/licenses/by-nc-nd/4.0/ 


\title{
Gauguin, Buffalo Bill, and the Cowboy Hat
}

\author{
Nancy Mowll Mathews
}

\section{Introduction}

As soon as he landed, Gauguin attracted the attention of the native people; they raised their eyebrows and joked about him, especially the women. He was tall, upright, and powerful, with an air of profound disdain, even though he was already curious about his new surroundings and undoubtedly worried about his future work there. [...] What drew so much attention to Gauguin was his long salt-andpepper hair, falling on his shoulders, under a large hat of brown felt with a wide brim like a cowboy's. ${ }^{1}$

1 This often-told story of Gauguin's arrival in Tahiti in May of 1891 was recounted by Lieutenant Paulin Jénot, who was stationed on Tahiti from 1890 to 1893. It has been elaborately parsed in art historical literature, primarily to understand more deeply his relationship to Polynesian culture-which formed the basis of his greatest art. Issues of colonialism, race, and gender, seen through the lens of Tahiti and later the Marquesas (Gauguin's homes for the last decade of his life), have occupied most recent Gauguin scholars (see Childs; Eisenman; Shackelford and Frèches-Thory). In the process, the long hair and hat, while acknowledged to be derived from Gauguin's experience of the 1889 performance of the Buffalo Bill Wild West (Mathews, 2001 150; Childs 70; Eisenman 27; Thomson, 201048 and 73), have been divorced from that source. This article reunites Gauguin with Buffalo Bill ${ }^{2}$ (Figures 1 and 2) rather than simply dismissing the hat and long hair as Gauguin's “sartorial eccentricity” (Eisenman 7). 
Figure 1

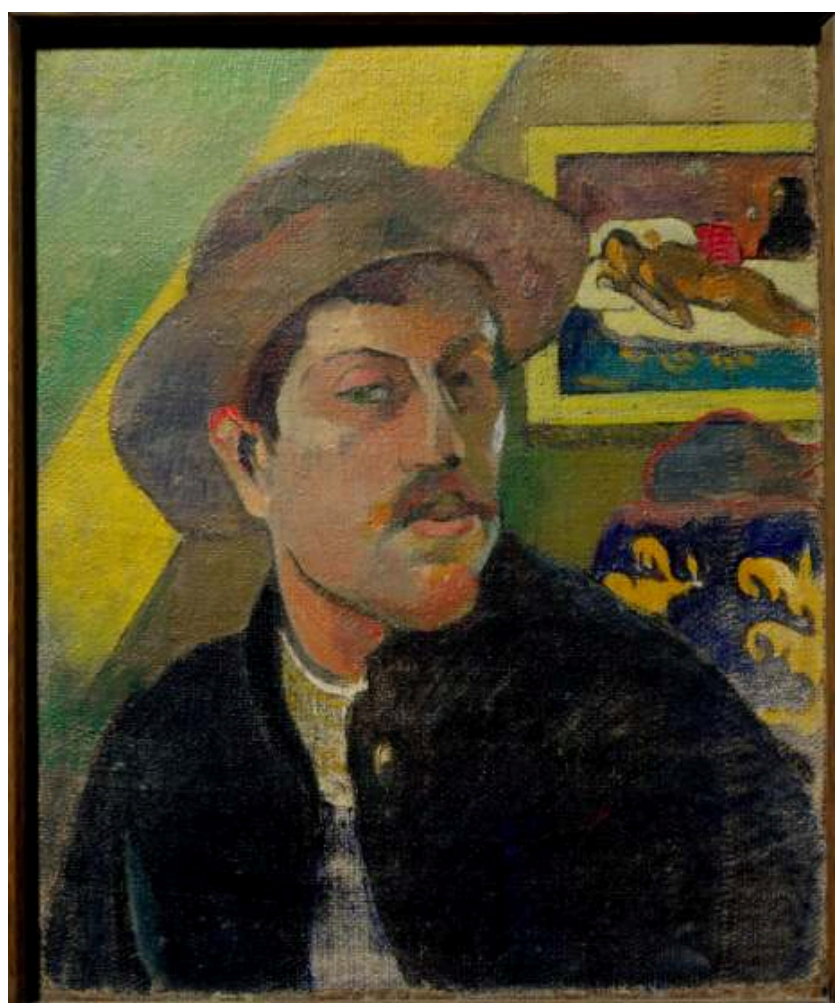

Paul Gauguin, Self-Portrait with a Hat, 1893-4, oil on canvas, 46 x 38 cm, Musée d'Orsay (c) Scala/Art Resource, NY, RF1966-7recto. Photo: Franck Raux.

\section{Figure 2}

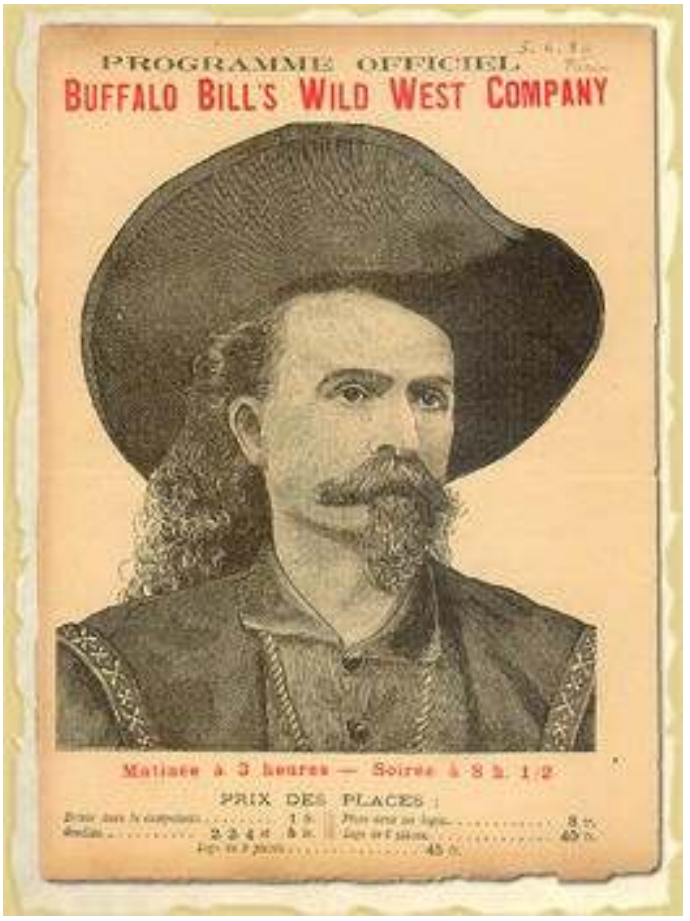

Petit Programme de 4 pages, Paris, 1889, collection Paul A. Pettet. http://oldwestamericana.overblog.com/article-10554477.html 
2 The essay shows how the artist absorbed Buffalo Bill's dual cowboy and Indian mythologies from his visits to the Wild West show, which ran alongside the 1889 Paris International Exposition. Gauguin brought to the Wild West in Neuilly his own recently-constructed identity as an American Indian (albeit Peruvian) and, in the years following-while in Brittany, Tahiti, and Paris-performed various aspects of the French interpretation of "Buffalo Bill" as applied to a pioneering modern artist. Gauguin's New World context was extensive, and included his Peruvian and other South American relatives, his art world audience of American artists and collectors, and, finally, his expatriation to the Pacific islands of Tahiti and the Marquesas. His adoption of the long hair and cowboy hat, made internationally famous by Buffalo Bill, gives us a key to understanding how he wove together the French and American cultural notions of primitivism, sexuality, leadership, and the avant-garde. And in turn it sheds new light on Buffalo Bill himself as we see him through the lens of the French avant-garde art community. In Gauguin's interpretation of "Buffalo Bill" and his gender performativity, as Judith Butler would call it (Butler 179), we gain a new appreciation of Cody's daring embrace of androgyny and rejection of the narrowness of western civilization, all of which makes him more "modernist" than the twentieth-century cowboy mythology has previously led us to believe.

\section{Gauguin at the Fair}

3 Like his arrival in Papeete, Gauguin's experience at the Exposition Universelle has been scrutinized by art historians primarily to understand his interaction with Polynesian, Southeast Asian, and other French colonial cultures. Most attention has been given to his response to the French colonial exhibits and "villages" at the Fair and the photography related to them (Childs 54-90; Druick and Zegers 101-42; Mu-Liepmann 80-94). In contrast, his multiple visits to the Wild West arena, a distance from the main campus of the Fair, are passed over as mere entertainment and not treated as an equally important clue to how he developed his ideas about nature, culture and civilization.

However, the encampment of cowboys and Indians in Neuilly was set up essentially as the other villages were: indigenous people were paid to travel to Paris to enact a "primitive" lifestyle, wearing exotic clothing and carrying out traditional activities associated with each culture (Childs 65-67). Often the village would also be the site of performances by the "natives," usually involving music and dancing. Gauguin went to the performances of battles and skills of the American West, but he would also have been able to wander around the cowboy and Indian camps and animal corrals, just as he would have at the colonial exhibits. Cody's very professional team had set up the site to be accessible to the fairgoers. Part of the appeal of the Wild West was its claim to authenticity compared to the other exhibits: it was perceived as more "authentic" because the Buffalo Bill staff arranged for the tents, animals, clothing, weapons, musical instruments, and other objects to be transported from the United States and set up according to their own designs. Some Buffalo Bill's Wild West scholars have argued that viewers believed that "Here was an experience of the real thing, of living history that had just passed" (Rydell and Kroes 116). The exhibits of the French colonies, on the other hand, were orchestrated by the Exposition's designers and achieved varying degrees of credibility (Childs 63). 
Gauguin's enthusiasm for Buffalo Bill's Wild West radiates from the letters he wrote to Emile Bernard, whom he pressed to accompany him to one of the performances: "J'ai été à Buffalo. Il faut à toute force que vous veniez voir cela. C'est d'un grand intérêt" (Gauguin, 1954 80, 81). This enthusiasm must be seen in light of Gauguin's larger purposes at the Fair, which were not as a casual tourist seeking entertainment, but to advance his interests as an artist. First, Gauguin and his friend Emile Schuffenecker were actively seeking an exhibiting venue in or near the grounds of the Fair for their group of progressive painters. By the end of May, they had secured the walls of a temporary restaurant called "Café des Arts" in the row of eateries on the grounds facing the Fine Arts Pavilion, and the "Volpini show" (named after the café's director) was hung by mid-June (Thomson, 2009 45).

6 Second, while visiting the Fair, Gauguin doubled as a modern art critic, writing about the shortcomings of the French section of the Fine Arts Pavilion and pointing out that it did not represent the latest forays into Symbolist or Post-Impressionist art (Gauguin, 1889a and 1889b). In addition, he analyzed other aspects of the Fair's design, writing eloquently about the modern aesthetics of iron to be seen in the Eiffel Tower. There is no reason to believe, therefore, that Gauguin did not also approach the Wild West encampment and spectacle with the same artistic inquiry he brought to everything from the Sèvres ceramics to the Javanese village.

7 And third, in terms of finding new markets for his work, Gauguin would also have been aware through extensive press coverage over the course of the Fair, if not word-ofmouth in the artistic community, that Cody was welcoming to artists at the encampment. He employed artists to paint the enormous panoramic backgrounds of Western scenes that lined the amphitheater so that the performances were themselves paintings come to life-"Artistically Blending Life-Like, Vivid, and Thrilling Pictures of Western Life" as an 1885 program described it (Warren 258). He also hired photographers, designers, and lithographers who produced the posters and programs seen throughout the city. He struck up a friendship with Rosa Bonheur, who became a kind of artist-in-residence in the fall, producing some fifty paintings and sketches not only of Buffalo Bill but of performers in the troupe (Figure 3) (Burns 64-78). It was reported that Cody himself was taking painting lessons from Bonheur; the Chicago Tribune reported in its "Personals" section, "Buffalo Bill and Rosa Bonheur have become great friends. The former is taking lessons in oils from the great artist" (4). Gauguin's support for the fine arts was primarily promotional, but nevertheless he encouraged artists whenever possible. 
Figure 3

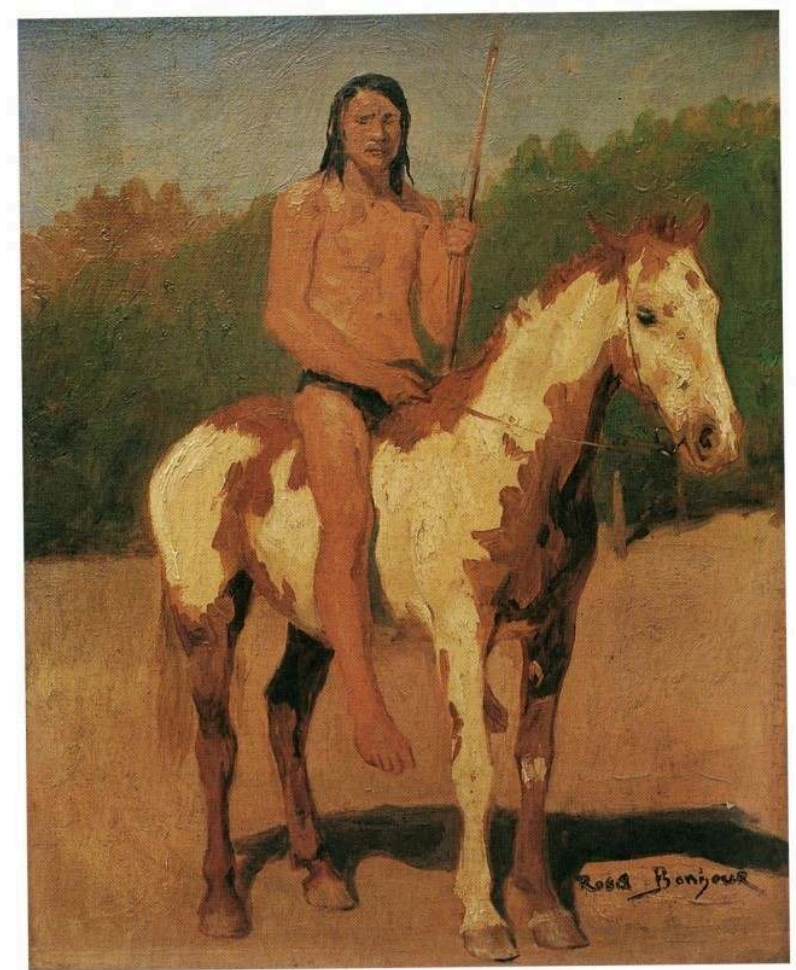

Rosa Bonheur, Native American on Horseback, 1889, oil on wood, $22 \mathrm{~cm} \times 29 \mathrm{~cm}$., Musée de la cooperation franco-américaine, Blérancourt, MNB2012.1.2. Photo: Stéphane Maréchalle.

(c) RMN-Grand Palais / Art Resource, N.Y.

Cody's interest in art would have been consistent with Gauguin's understanding of the emerging American art market. In Pont-Aven, Gauguin was surrounded by American artists who admired his work, and he was aware that French artists and dealers were increasingly finding success in that country. Bonheur, for example, had a large and lucrative American following. Her monumental Horse Fair (1852-1855) had just been given to the new Metropolitan Museum in New York in 1887 and was one of the most celebrated works of its day (Weisberg 1-22). The art dealer Paul Durand-Ruel, so important to the progressive artists of Paris, including Gauguin, had held a major Impressionist exhibition in New York in 1886 and then opened a branch gallery there in 1888. Gauguin felt there might be an American market for his work: "My painting arouses much discussion, and I must say it finds a fairly favorable reception among the Americans. There is hope for the future." ${ }^{3}$ When Gauguin urged Bernard to make the trip out to Neuilly, it was not solely for amusement, but also as a chance to explore new artistic opportunities.

\section{Gauguin as Indian: Europe, America and his concept of "savage"}

9 A sketchbook ${ }^{4}$ from Gauguin's trip to Paris in 1889 shows pencil notations of a wide range of artistic impressions from Assyrian sculpture in the Louvre to fashionable women on the street. Drawings of various displays at the Fair have been identified, as well as a number of quick sketches of horses and riders (Druick and Zegers 135). A 
separate, independent sheet of drawings shows on the right a nude male in various positions of mounting a horse, while on the other side there are several notations of a man with long hair wearing a hat with a curled brim (Figure 4). This drawing has yet to be definitively dated, but a strong case can be made to tie these images to the Wild West display. Drawings by Bonheur based on photographs from the performance grounds (perhaps made by Bonheur), suggest that some American Indian performers in the Wild West rode horseback wearing loincloths or that they posed in this way. Bonheur painted several versions of this subject (Figure 3) (Burns 70-71). These drawings show Gauguin's interest in male nudity in action poses, which can be tied to recent paintings from Pont-Aven, such as Two Boys Wrestling (1888, private collection). Observation of primitive, "natural" behavior, such as nudity outdoors while fighting or riding was typical of European fantasies about less civilized world cultures, even folk cultures within Europe itself. ${ }^{5}$

Figure 4

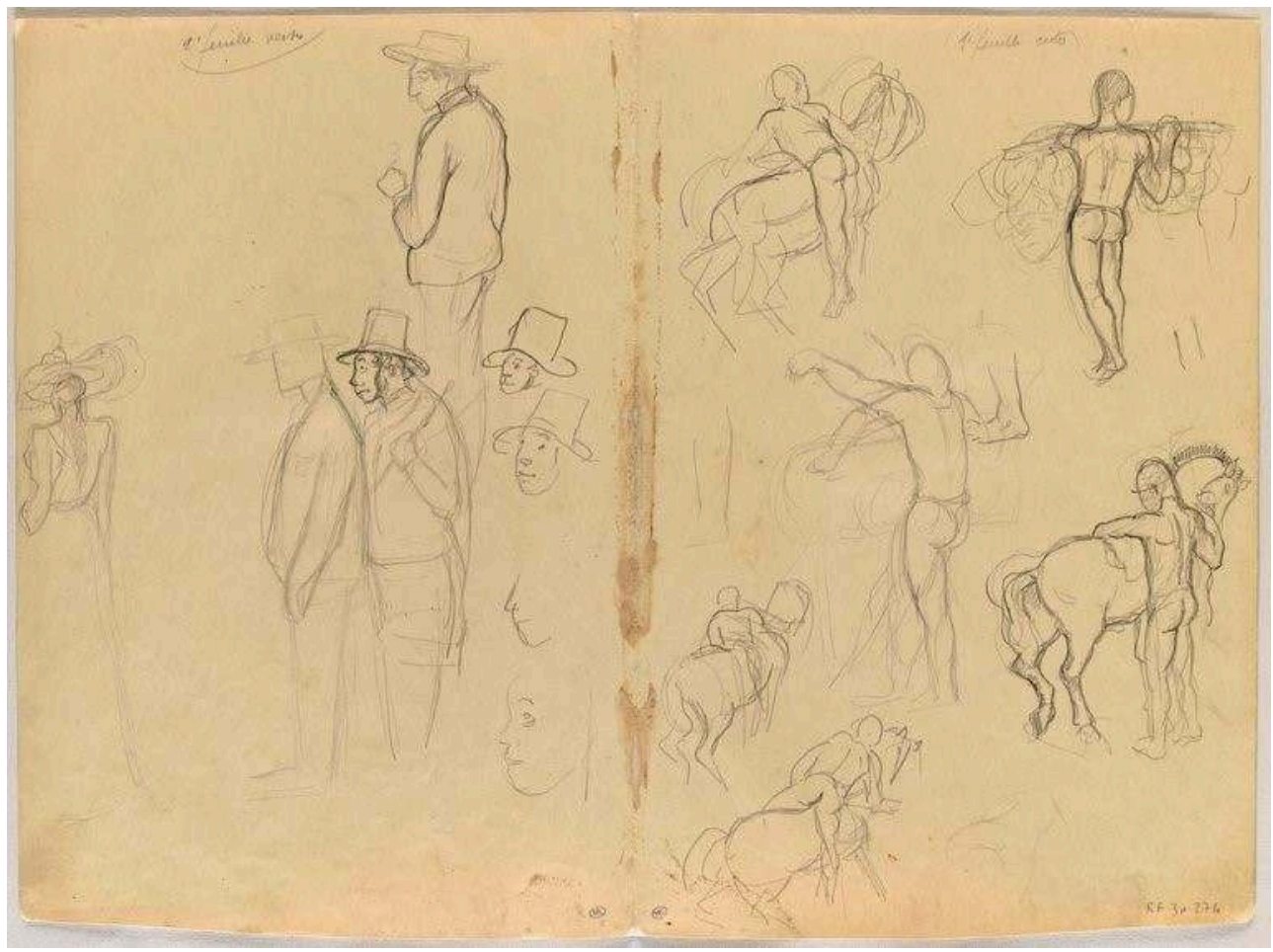

Paul Gauguin, Hommes, de profil; femme de dos; un porteur; six études d'un cavalier, c. 1889. Photo: Adrien Didierjean Musée d'Orsay, Paris, France, RF 30274, Recto

(C) RMN-Grand Palais / Art Resource, NY

But Gauguin had another, more personal reason for gravitating toward the subject of primitive behavior, because he increasingly called upon his own Peruvian heritage to claim authentic status as a "savage." When he went to see the Wild West exhibition of "historic" American culture, he may have had a special interest in it because he was himself part American, thanks to his great-grandfather, Don Mariano de Tristan Moscoso (1760-1807). Don Moscoso was from an old Spanish-Peruvian family, who crossed the ocean for his education and military service, married a French woman, and settled in Paris. The Gauguin family in France kept up the connection to the Peruvian relatives after having spent a few years in Lima when Gauguin was a young child. Many 
of them visited Paris, and Gauguin's mother had close ties to the South American colony in that cosmopolitan city. Gauguin's sister Marie married a Columbian businessman, and it was to join his business that Gauguin had made a journey to Panama (then a part of Columbia) in $1887 .{ }^{6}$ Most of Gauguin's extensive travels before he went to Tahiti were to the Americas. ${ }^{7}$ It is also worth noting that the Impressionists that Gauguin gravitated toward-Degas, Pissarro, and Cassatt-were in some way connected to the Americas. Cassatt was from Pennsylvania; Degas's mother was from New Orleans, and Pissarro grew up on St. Thomas in the Caribbean.

11 In anticipation of the trip to Panama, Gauguin began to express his inner feelings of "wildness." Despite the fact that his mission was to join his brother-in-law's retail business in Panama City, one of the gracious old Spanish capitals of the Americas, he imagined a life in the untamed part of the New World. He wrote of this wildness to his wife, with whom he had a rocky and sometimes violent relationship. After leaving her with the five children, he often expressed his desire to be freed from society's strictures. In the remote parts of the Americas, such as the island of Taboga in the Gulf of Panama, he felt he can paint without worry if he lives "en sauvage" [in the wild] (Merlhès 122). Furthermore, he writes in his next letter that he has two sides to himthe loving family man, but also, if provoked, "the wild beast."

The theme of dual identity-the well-behaved and responsible gentleman if all goes well, but the uncivilized savage if thwarted-tipped toward the "Indian" after he returned from his time in Panama and the Caribbean island of Martinique. In early 1887, before he left, he had exhibited inventive ceramics for which he had drawn on so

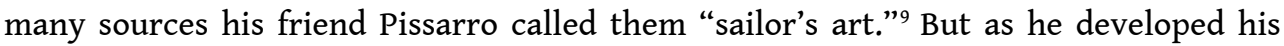
potter's craft, he foregrounded the Peruvian tradition which was well known and highly collectable in Paris, and of which his family and friends had many examples. By January of 1888, Theo Van Gogh exhibited a combination of Gauguin's paintings from Martinique and his new ceramics in which the "American" element was clearly discernable. One of the pieces, much admired by the art critic Félix Fénéon, depicted the last tragic Inca ruler, Atahualpa, who had been executed by the Spanish. Atahualpa's martyrdom ended the rule of native peoples in that part of South America (Chung 23).

13 Gauguin's noble, martyred "savage" identity takes shape in these years as an American Indian, albeit Peruvian..$^{10}$ Perhaps encouraged by new friends, the well-read, philosophical artists Emile Bernard and Vincent Van Gogh, Gauguin evoked his Peruvian heritage throughout 1888. He wrote to Schuffenecker about his new PontAven painting of two boys wrestling that it was Japanese in inspiration, but painted by "a savage from Peru [sauvage du Pérou]" (July 8, 1888, Merlhès 156). Soon after, he inscribed the famous Vision After the Sermon (Scottish National Gallery, Edinburgh, UK) "A Gift of Don Tristan de Moscoso" (Gauguin's Peruvian great-grandfather) when he attempted but failed to present it to a church near Pont-Aven. It was this constructed hybrid identity, claiming both European and Indian blood, that Gauguin brought to Cody's Wild West show in 1889.

In the performances, Gauguin may have noticed that the narrative of "civilization" imposed upon the Indian "savages" included Mexican vaqueros and French trappers as well as American cowboys, recognizing similar historical movements north and south of the US borders. There was no question that the Buffalo Bill concept was the story of European transformation of the entire length and breadth of the Americas. In this it 
paralleled the main theme of the Exposition Universelle: Europe bringing civilization to the world through colonization, technology, education, and trade.

But the Wild West's relationship with that narrative was complicated. It reinforced the idea of a spreading civilization, but it also diverged from the assumptions of the rest of the Fair in that the performance celebrated both cowboys and Indians, and in some ways merged the two. It brought to life one of the longstanding fantasies of the American West in which the cowboys (mostly of European descent) and the native (Indian) braves bond (Rydell and Kroes 111). In Gauguin's case, the distinction between cowboy and Indian was blurred in his mind. He wrote from the seaside village of Le Pouldu in the summer of 1890: "I [...] walk about like a savage, with long hair, and do nothing [...]. I have cut some arrows and amuse myself on the sands by shooting them just like Buffalo Bill." ([June 1890], Malingue 110). In this, he uses the term "Buffalo Bill" loosely to refer to the whole spectacle rather than referring to William Cody as an individual, and his emphasis is on the Indians with their low-tech arrows rather than the cowboys with their state-of-the-art guns (Rydell and Kroes 113).

In the two years between Gauguin's experiences at the 1889 World's Fair and his 1891 departure for Tahiti, the artist was able to clarify his opposition to "civilization," which he saw not only as European culture but as any onerous bureaucratic regulation, from the conventions of marriage to the rule of the French Academy over the arts. He was less political than Van Gogh, who opposed European colonization of distant lands like the Marquesas ${ }^{11}$ in a conventional left-wing manner, or even than Bonheur, who sympathized with the poor treatment of American Indians (Burns 68-69). Rather, it was his belief that regulation was harmful to the instinctual flow of nature.

17 This is not to say that Gauguin was not aware of and sympathetic toward the loss of indigenous cultures through European contact. And in later years, Gauguin would produce protest literature on the themes of the colonial government in Polynesia and the Catholic Church, among other social issues. But he was primarily concerned with his own symbolist art production, as Belinda Thomson argues (Thomson, 2010 11). As an "Indian" himself, he resented the tyranny of conventional family life, the injustice of artists having to work for money, and anything that prevented him from producing beautiful art. Art, he felt, must flow from the union of his inner untamed nature and a world unsullied by modern western society. As Vincent Gille points out, Gauguin's belief was that his artistic center was in his own mind (Thomson, 2010 53).

As Gauguin was about to leave for Tahiti, he gave an extensive interview to poet and critic Octave Mirbeau who published two articles on the artist in L'Echo de Paris (1890) and Le Figaro (1891). Gauguin stressed his family lineage, including giving the false impression that his mother was born in Peru (she was born in Paris). Mirbeau concludes from Gauguin's strong ties to the New World-specifically the Pacific coast of the Americas-that his trip to the Pacific island of Tahiti is in a sense returning to his natural home: "he would become nostalgically obsessed with those suns, those races, that flora, and with the Pacific Ocean, where he was surprised to find the cradle of his own race and which seems to have rocked him in bygone times with familiar lullabies" (quoted in Mathews, 2001 158).

In Mirbeau's essay, Tahiti ("the cradle of his own race") serves as a land of native peoples similar to Gauguin's assumed "Inca" identity. Merging "Indian" identity into international exoticism continues into today's scholarship as, for example, in JeanFrançois Staszak's 2004 essay on primitivism or Vincent Gille's essay, "The Last 
Orientalist: Portrait of the Artist as Mohican" (Thomson and Garb 48). Gille reproduces a now lost self-portrait sketch "as an Indian" but merely uses Gauguin's Indian identity as a stepping stone to his interest in international exoticism.

It also serves as a reminder of Gauguin's "American" identity. Although largely a French territory, Polynesia was dominated by North and South American Pacific commerce. In the eighteenth century, Spain had attempted to colonize Tahiti (1772-1775) to protect its Peruvian interests before Britain and then France took over, annexing it in 1880. Trade with Chile and Peru continued throughout, and until the end of the nineteenth century, Tahiti used the "Chilean Dollar" [peso] as currency like most of the Polynesian islands (Gilson 80). Neither Gauguin nor Mirbeau may have known the specifics of the South American/Tahitian historical circumstance, but from their vantage point in Paris, that part of the world might have seemed sufficiently connected.

\section{Gauguin as Cowboy: Sexuality, d'Artagnan, and the Scout}

Never in the islanders' memory had there been a long-haired man on Tahiti, except for the Chinese, who did not have the same appearance. Immediately Gauguin was nicknamed taata vahine (man-woman) which the natives meant in jest, but which provoked such curiosity among the women and children that I was obliged to shoo them away from my house. Gauguin, who was soon made aware of this, laughed at first, but, after a few weeks, thanks also to the heat, he had his hair cut off in the normal way. ${ }^{12}$

By the time Gauguin arrived in Tahiti, however, he presented yet another side of the complex Buffalo Bill construct. If he had solely intended to display a kinship with the native people of the Pacific New World as Mirbeau's article implied, he would have conformed to an appearance more in keeping with the local styles and customs. After all, the long voyage to Tahiti meant he had already been in the tropics for some weeks and had had a chance to observe local people while docked in tropical ports. Instead he deliberately grew his hair long and donned a hat that had been designed for a hot, dry climate-which must have been stifling in the Tahitian humidity. The combination of the two not only made Gauguin look like an American cowboy rather than a Tahitian "primitive"-but specifically like Buffalo Bill.

Today we have lost the keen sensitivity to the symbolism of the hat-both men's and women's-that held sway in the later nineteenth century. "Men are known by their hats," an American commentator on fashion wrote in 1883: "[They] may contrive to make every other article of their apparel lie and dissemble, but truth clings to a hat. [...] Look at it and read its owner's mind" (Detroit Free Press, 18832 2) ${ }^{13}$ As documented by C.S. Reinhart (Figure 5), hats were of special interest at the Paris International Exposition of 1889 because of its emphasis on non-European cultures and the multi-ethnic audiences to be observed on the grounds of the Fair. Souvenirs, including exotic items of costume, were sold in the official shops as well as throughout the city of Paris. Jill Jonnes quotes Cody's observation that "Cowboy hats appeared everywhere on the street" (125). It is likely that Gauguin purchased his cowboy hat at the time, as did prominent men across Europe, including Prince Bismarck of Germany who was noted wearing "a soft hat with a high brim, a sort of cowboy hat" at a reception in Homburg in 1890 (Chicago Daily Tribune 5). 


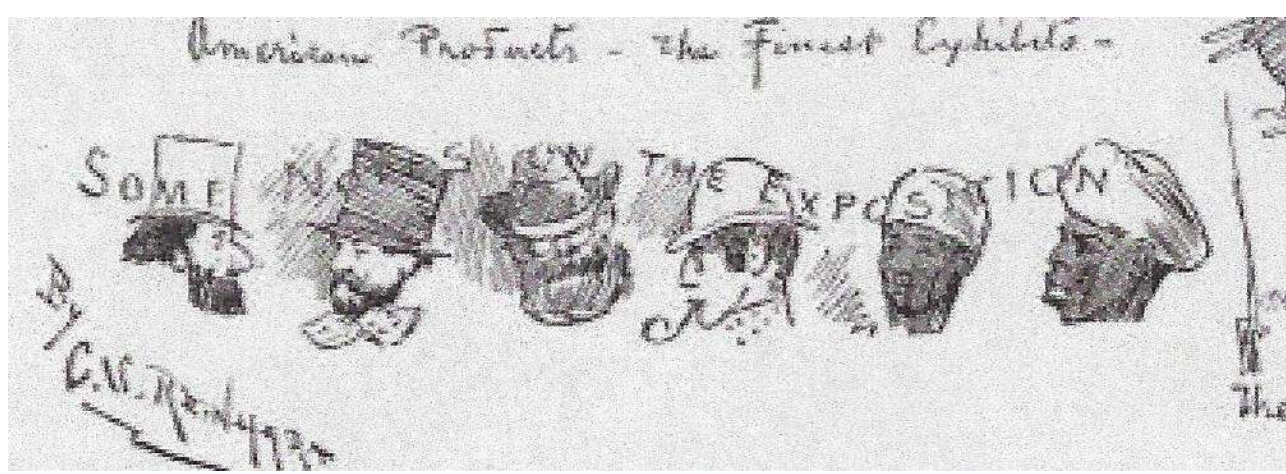

C.S. Reinhart, detail from "Sketches from the Paris Exposition." Harper's Weekly, vol. 33, n. 1062, June 22, 1889, 492.

Gauguin was known for wearing hats as costume rather than as a simple statement of social class. While Whistler, for example, wore a silk top hat to conduct business at the exhibition of his work at the 1889 Fair (Jonnes 85), Gauguin was better known for wearing a beret, which could connote his artist's status, but also gave the impression of a man of authority: "His general appearance, walk and all, was rather that of a well-todo Biscayan skipper of a coasting schooner" (Hartrick 31). Later, during his return trip to Paris in 1893-5, he wore an Astrakhan hat from southern Russia, and within a few months of each other, he painted two self-portraits-one with the Astrakhan and the other evoking the American cowboy (Figure 1). All of these costumes suggested the outdoor life, travel over great distances, and soft, malleable materials at odds with the stiff frames of city hats. When Gauguin chose the cowboy hat for his entrance into Tahiti in 1891, he was doing so at the height of Buffalo Bill's popularity, and we can explore the international understanding of that look as tied to Buffalo Bill himself.

\section{Cowboy Sexuality}

As Lieutenant Jénot noted, the foremost response to Gauguin's entry into Tahiti with long hair and cowboy hat was to question his sexuality. The immediate issues of Gauguin and gender and race identities in Polynesia have been explored convincingly by Stephen Eisenman in his influential 1997 book, Gauguin's Skirt. In his chapter "Sex in Tahiti," Eisenman writes of the European and Tahitian attitudes toward "sexual dimorphism" (the male-female binary) at the time of Gauguin's arrival there. He explores the Polynesian traditions of non-dimorphic sexuality, particularly the acceptance of the "female" male ( $m a h u$ ). Similarly Gauguin was part of the European intellectual circles exploring androgyny and "inversion" as represented by such celebrities as Oscar Wilde and Gauguin's friend Paul Verlaine (Eisenman 94-95). The "skirt" (pareu) worn by men in Tahitian traditional dress provides the pivot around which Eisenman discusses Gauguin's experience of and representation of this challenge to traditional European binary sexuality.

To expand the discourse, however, we can add the androgynous character of the cowboy hat itself. By the late 1880s when William Cody brought his Wild West to Paris, the western hat coupled with unusually long hair had already been featured in nontraditionally masculine ways. In New York, as in Papeete, Cody could not walk down 
Broadway without eliciting a similar response from native New Yorkers, who laughed at his "wide-brimmed hat and the long, curling hair" (Wall 26) (Figure 6). While Cody's masculinist sexuality was not in question, he courted the theatrical transgression of this androgynous appearance.

Figure 6

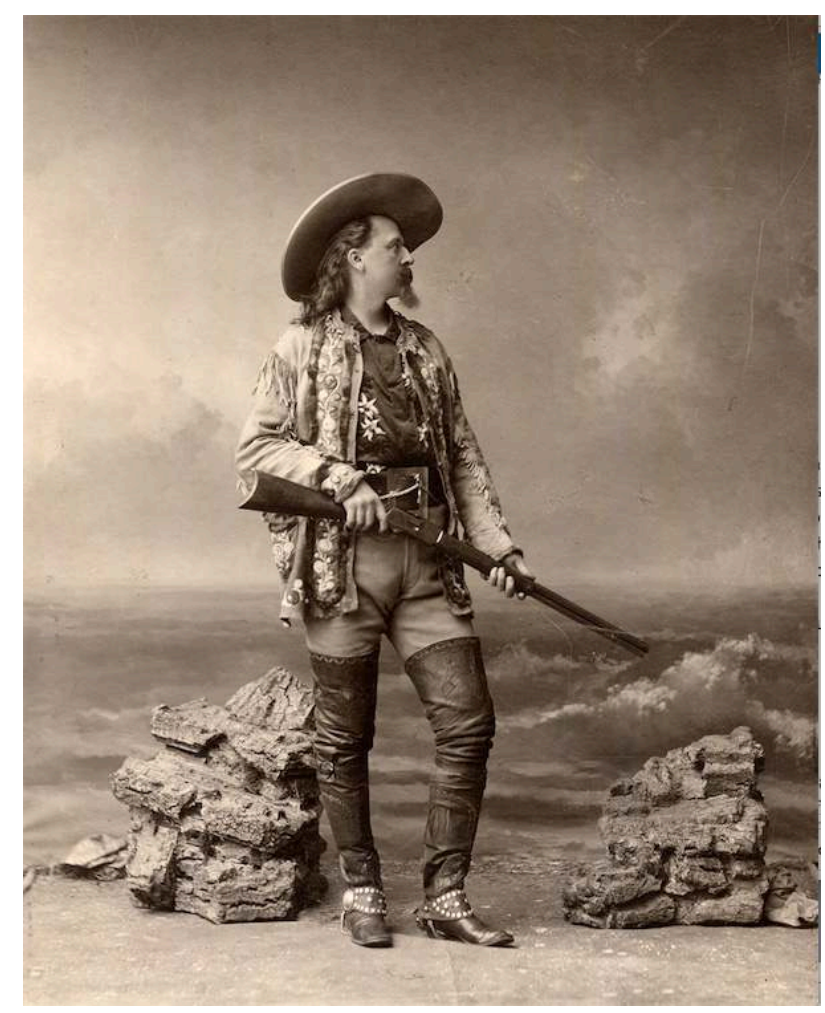

WILLIAM F. (BUFFALO BILL) CODY, C. 1888, BUFFALO BILL MUSEUM AND GRAVE, GOLDEN, CO 
Figure 7

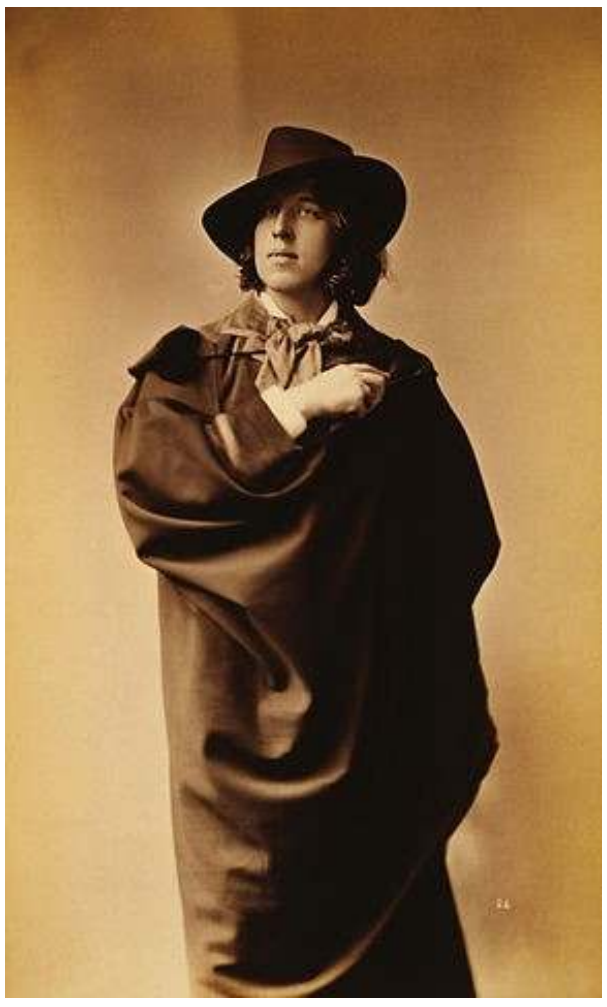

Napoleon Sarony, Oscar Wilde, 1882, albumen print, 30.7 x $18.2 \mathrm{~cm}$., Library of Congress, Prints and Photographs Division

Oscar Wilde, on the other hand, who was not as traditionally masculine, advertised his lecture tour throughout the United States in 1882-3 with photographs of himself wearing a cape and cowboy hat and frequently wore this outfit when traveling (Figure 7).$^{14}$ He lectured on decorative art, including fashion, declaring that American western miners were the best-dressed men in that country. "Their wide-brimmed hats, which shaded their faces from the sun and protected them from the rain, and the cloak, which is by far the most beautiful piece of drapery ever invented, may well be dwelt on with admiration" (Wilde). Upon Wilde's return from the United States in early 1883 he traveled to Paris, where, with Whistler, he socialized with members of the Impressionist group ${ }^{15}$ perhaps including Gauguin, and perhaps still wearing the cowboy hat. 
Figure 8

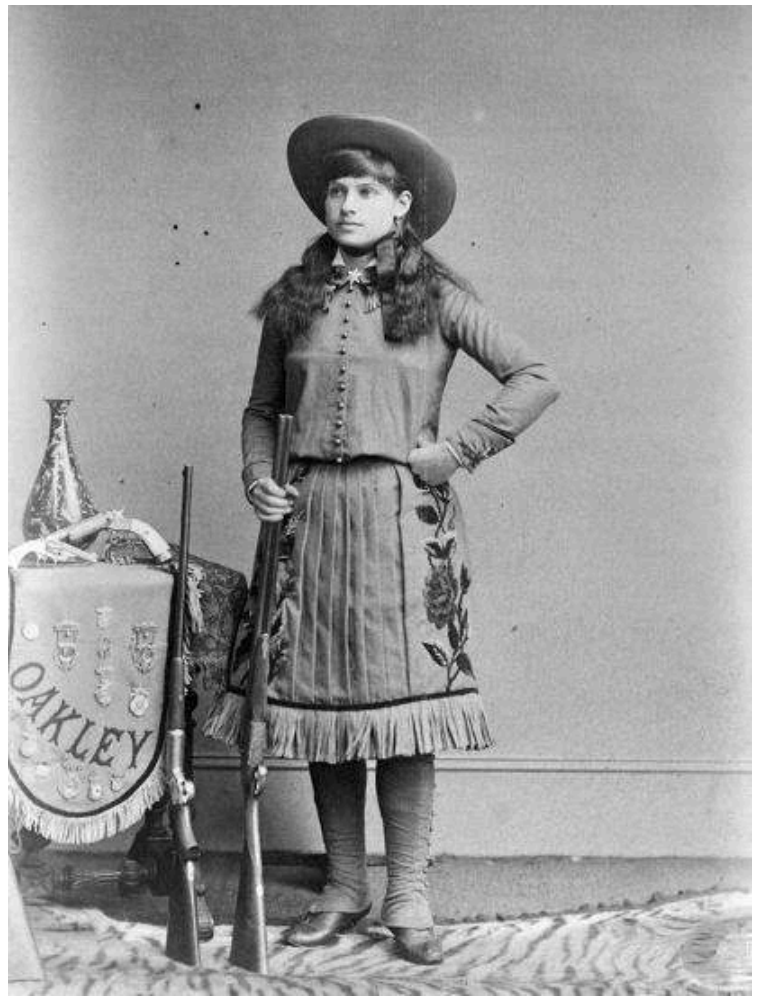

Elliott and Fry, Miss Annie Oakley, Little sure shot, Buffalo Bill's Wild West, c. 1890-1900, photograph, 17 x $11 \mathrm{~cm}$., Denver Public Library, Western History Collection, Z-330

Men such as William Cody and Oscar Wilde used the long hair and cowboy hat to attract attention and advertise their artistic freedom, flirting with androgyny. The androgynous look became popular for women too, with the rise of celebrity cowgirls like Annie Oakley later in the 1880s (Figure 8). The cowgirl, with her long hair, hat and firearms, was already a popular character in Western fiction in the 1880s, and the Wild West performances in Paris in 1889 featured Annie Oakley and other women skilled in the western arts of riding and shooting. This was not lost on the fashion world in Paris -along with the colors "Eiffel red" and "electric blue," "cowboy" dresses and hats made an appearance on women and even children (Boston Daily Globe 23). Gauguin may have embraced the gender elision of the cowboy style (long hair and hat) because it fit with the current vogue for androgyny among the artists in his radical circles. He urged Bernard's sister, Madeleine, for instance, to strive for androgyny and "find happiness solely in your independence and your conscience" ([mid-October 1888], Merlhès 173). In Tahiti, Gauguin's androgyny is thus not only to be seen in the context of the Polynesian mahu, but in the French/American gender performance as interpreted by Gauguin under the inspiration of Buffalo Bill.

Even if the overt frisson of androgyny was not the goal, the "cowboy look" was considered highly attractive in both American and European society in the 1880s. In the United States, many men in the Western United States wore this style of long hair and hat, but Cody's unique combination of headgear, fringed clothing, and tall boots made critics of fashion believe he had constructed his own individual look. "Buffalo Bill is one of the best dressed men I ever saw [...] when he walks along Broadway all stare and some laugh at his wide-brimmed hat and the long, curling hair beneath. Yet he has 
reached perfection [...]" said E. Berry Wall of the Chicago Daily Tribune, explaining that "perfection" is judged by the unique contributions he has made and how he has distinguished himself (1889 26). Similarly, a reporter for the Detroit Free Press concluded, "People may smile at the sort of vanity which prompts the wearing of long hair and fantastical costume [...] but the fact remains that the gentleman has an army record and a share in the history of the Far West which give good reason for such pride" (1885 8).

Furthermore, the greatest testament to the success of Buffalo Bill's appearance was that men and women flocked to him wherever he went. "There is something about the long hair, the bronzed faces and picturesque trappings of the cowboy, the Mexican vaqueros and the original American, the Indian, which have a peculiarly deep interest to the excitement-loving citizen of the United States" (1885 8). While the look might at first appear feminized or even ridiculous, Buffalo Bill had turned it into a thrilling, counter-culture style for a man of recognized skill. Other prestigious men, such as presidents Theodore Roosevelt, William Henry Harrison, and Grover Cleveland wore similar hats, as did Civil War veterans.

The Buffalo Bill look easily transferred across the ocean where Cody triumphed in England in 1887 and in Paris and around Europe in 1889-90. The American press followed his every move as he was lionized by the cream of Old Paris. "Many beautiful women squabble for the honor of lunching [with] le charmant Guillaume, and for these fair admirers the name of Buffalistes has been invented" (Washington Post 4). Lieutenant Jénot who had come from France for only a few years' duty in French Polynesia quickly recognized the cowboy hat, and surely also recognized the allusion to Buffalo Bill. His more worldly admiration of Gauguin's masculine sexuality, despite or because of the long hair, was the typical response to Buffalo Bill in western capitals.

\section{Buffalo Bill as d'Artagnan}

31 But, in 1891, Buffalo Bill was not just considered a handsome man. From the beginning of Cody's career as a character in the American popular imagination, he was portrayed as more than an adventurer-he was a leader, called "Knight of the Plains" and "Chief of Scouts." In 1887, the state of Nebraska conferred upon him the rank of "Colonel," a title he used liberally for the rest of his life. During the Wild West's 1887 tour in Great Britain, his company produced a poster (Figure 9) showing him leading an honor guard of horsemen from many states and nations, with the flagbearer from United States in front of those carrying flags suggestive of France and England among others. His noble long hair is exposed while he waves the cowboy hat in a salute. 


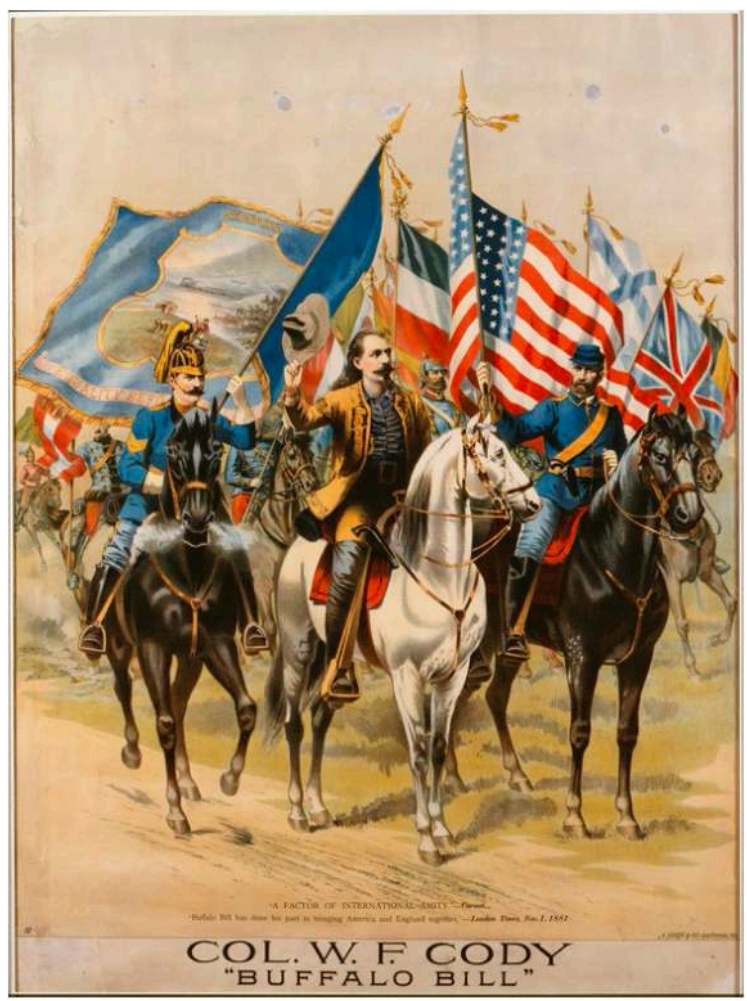

A Factor of International Amity: Col. W.F. Cody, "Buffalo Bill." Baltimore, MD: A. Hoen \& Co., The William F. Cody Archive, Buffalo Bill Center of the West, Cody, Wyoming, USA; 1.69.171b.

When Cody was in Paris, the public response recognized his noble contributions in what were considered both essentially French and essentially American ways. As for the former, Buffalo Bill was called in the French press an American "d'Artagnan, complete with the flowing tresses and thigh high soft leather boots" (Jonnes 130). The leader of the Three Musketeers of Alexandre Dumas' historical novel (serialized 1844), d'Artagnan in the nineteenth century was a symbol of modern Republican values-a man of idealism and strength fighting for liberty, equality, and fraternity against the Old Order (Ancien Régime) (Petit-Rasselle 185). This parallel was especially potent during the 1889 Fair's celebration of the storming of the Bastille and the start of the French Revolution. The sympathetic bond between the United States and France harkened back to their similar revolutionary beginnings as republics and self-appointed guardians of liberty throughout the world. ${ }^{16}$ In the art world, the issue of liberty was especially timely in regard to the recent Impressionist rebellion against the State-run Academy. Some American writers thought that in the matter of modern art, the French were following America's lead "in allowing artists to work out their own salvation without State interference" (New York Times, 1892 19). One American writer even referred to the Impressionists as "redskins," for their "ferocious attacks" on the established order (New York Times, 1879 2).

If Gauguin wore the long hair and cowboy hat of the French idea of Buffalo Bill as d'Artagnan when arriving in Tahiti, it would suit his self-image as a leader of a modern movement. Many observers of the modern art scene in and around Paris saw Gauguin as "the master," inspiring his young followers to find new paths. The landscape painter Maxime Maufra described Gauguin's entrance into Pont-Aven on Bastille Day, 1890: 
"One by one from this old peasant conveyance descended an evil-looking redskin [Gauguin,] a young blond man with a Christ-like face, and a little hunchback wearing a scarlet fez. Another big man with a frozen smile came last. It was Gauguin and his disciples: Filiger, de Haan, and Sérusier" (Maufra quoted in Mathews, 2001 151). While the reference to Gauguin as an "evil redskin" matches his own description of himself shooting arrows on the beach that summer, in this case he clearly is the leader of the "Three [Artistic] Musketeers" like d'Artagnan-and this time like Buffalo Bill rather than one of the American Indian performers in his troupe.

\section{Buffalo Bill as Scout}

But when Gauguin landed in Papeete, he came alone. He may have thought of himself as the leader of a revolutionary movement, but in fact he faced the unknown new land by himself. In this, the cowboy hat referenced another French response to Buffalo Bill, the more American concept of the "Scout," promoted by Buffalo Bill himself and celebrated in Bonheur's well-publicized portrait (Figure 10). Today, the heroic significance of the scout is less well understood, but in the 1880s, it had a powerful place in the European and American imagination. According to common definitions, such as H.L. Scott's Military Dictionary of 1861, a scout is a horseman "sent in advance, or on the flanks to give an account of the force and movements of the enemy"," or a military avant garde. In the post-Civil War era in the United States, however, many soldiers went West to serve as civilian scouts for army posts in the Indian territories, thus associating the term with American westward exploration and expansion. The term was also applied to Indians trained as trackers in the popular novels of the French author Gustave Aimard (1818-1883) such as Eclaireur (The Indian Scout) which was published in French and English in 1861. With the additional association of the term with Indians, it conveyed a special knowledge of the natural world. For those, like Cody, who combined the heroic military scout with traditional Indian scouting skills, there was a special term-“White Indian": "If Indians embodied Nature and Europeans embodied Culture, the white Indian embodied the proper, virtuous mixing of both" (Warren 82). 
Figure 10

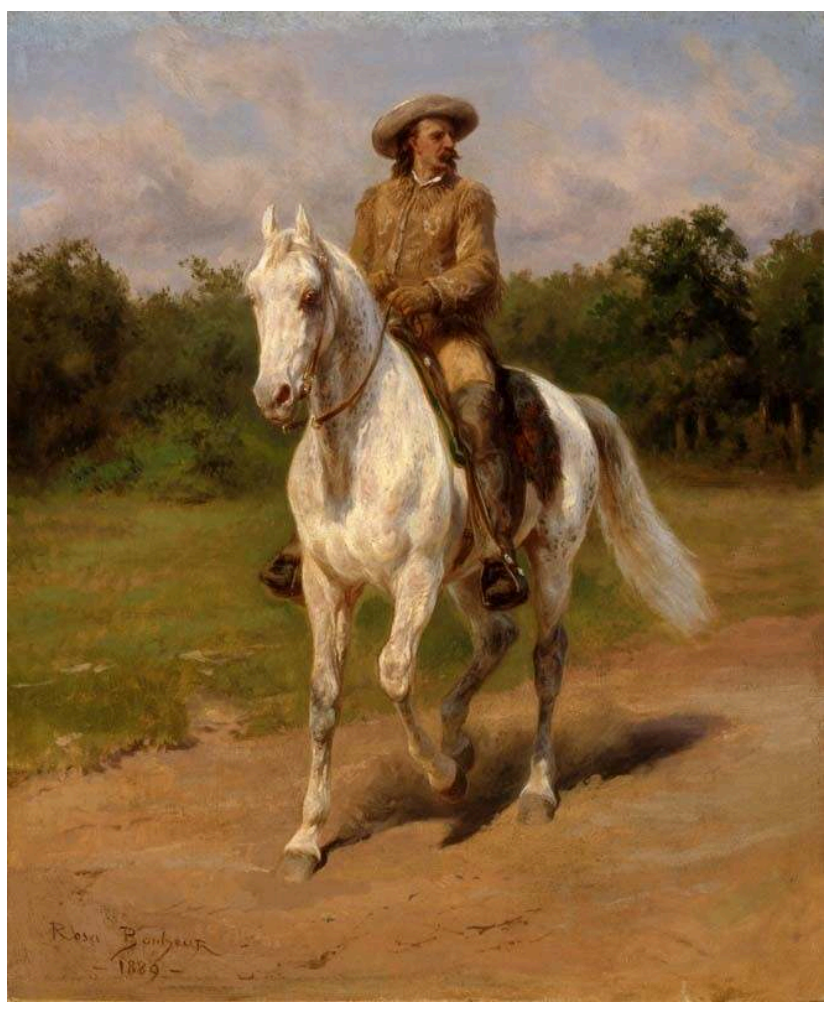

Rosa Bonheur, William F. Cody, 1889, oil on canvas, 47 x $38.7 \mathrm{~cm}$. Whitney Western Art Museum, Buffalo Bill Center of the West, Given in memory of William R. Coe and Mai Rogers Coe, 8.66 


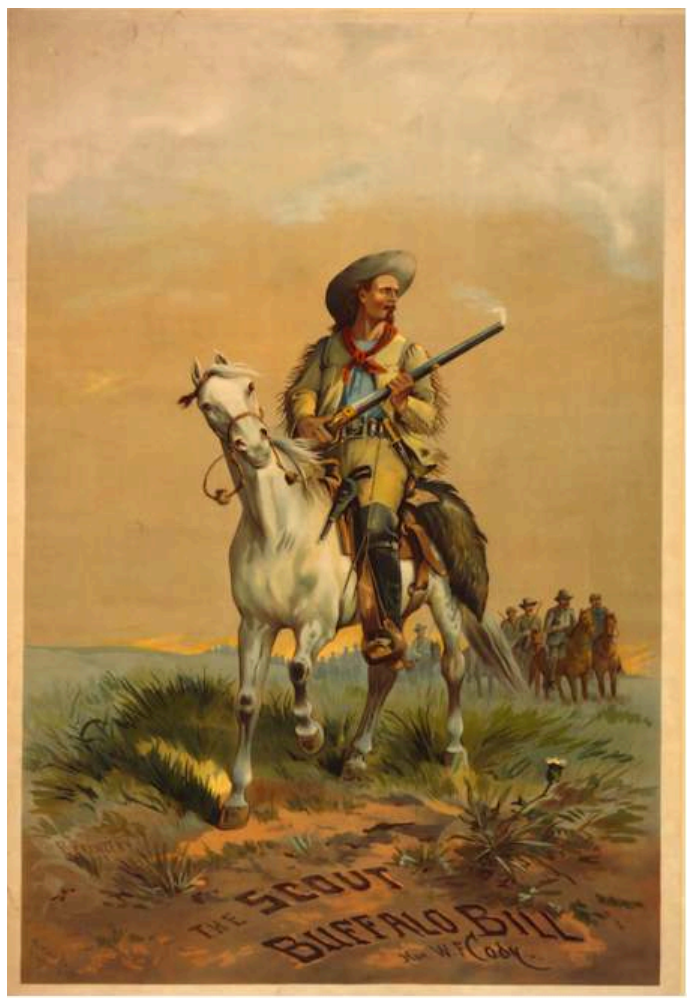

The Scout Buffalo Bill Hon. William F.Cody, c. 1883, color lithograph, Boston: Forbes Co., Library of Congress, Prints and Photographs Division

The term "Scout" was well-earned and deeply treasured by Cody himself. He served briefly in the Civil War, becoming scout and dispatch bearer for General William Tecumseh Sherman in 1865 at the age of nineteen. By 1868, he was scout and guide for the Fifth U.S. Calvary, and by 1869 the first dime novel about his adventures was published (Cody Archive/Chronology). In the 1870s he began his theatrical career, first in "Scouts of the Prairie," a play based on his life, and then in his own "Buffalo Bill" touring company (Kasson 459-60; Warren 84-93). All the while, he continued to serve as a civilian scout for the army and a guide for celebrity hunting parties. "The Scout" became his official nickname, as can be seen in promotional broadsides (Figure 11). It was this identity that Bonheur chose, showing the man on horseback, in advance of his troops, his alert gaze sweeping the distant horizon. In her interpretation, the troops are no longer visible, stressing the trait of individuality and self-reliance of the man exploring new, "uncivilized" lands.

The hat in Gauguin's Self-Portrait with Hat (Figure 1), which gives us a sense of Gauguin's appearance in Tahiti, would have been referred to in American parlance as a "slouch" hat, usually associated with scouts (New York Times 1884). Although the Stetson company "invented" it in 1865, it was a combination of a traditional Spanish vaquero's hat and a Civil War scout or artillery hat. The curled-up brim, as Buffalo Bill wore it, indicated a soldier on horseback who needed to be able to raise his musket up to his ear to get a perfect aim. But the hat itself was made without the curl in the brim so that it could be tailored to the individual. The soft, durable felt made of either fur or wool was unique in this way, and these hats were more expensive than a typical man's bowler, or even a top hat, that would be made out of stiffer materials. ${ }^{17}$ The slouch or "cowboy" 
hat came to symbolize the spirit of the West, "a spirit that gave to a man an intense individualism" (Rollins 347).

We cannot be sure that the hat Gauguin wears in his self-portrait of 1893-4 (Figure 1) is the same one Lieutenant Jénot described in his account of the landing in Papeete, but it is brown, looks soft like felt, and has a wide brim. We may get another glimpse of it in two photographs taken in conjunction with his exhibition at the Galerie Durand-Ruel in the fall of 1893 where we can see such a hat in greater detail (Figures 12 and 13). Scholars disagree about whether these were taken at the gallery itself or in Gauguin's studio, but the informality of the group picture argues for the latter. It is even hard to tell if it is Gauguin himself wearing the hat in the group picture, but the presence of such a garment in this context is telling in and of itself. What we do know is that the portrait photograph was sent out with Durand-Ruel's press materials since it was published in a review of the exhibition in February of 1894 (Groom 23, 68). In these images, we can imagine Jénot's Gauguin, and, although they were created after his return to Paris, the Tahitian paintings on the wall behind him evoke that fateful moment.

Figure 12

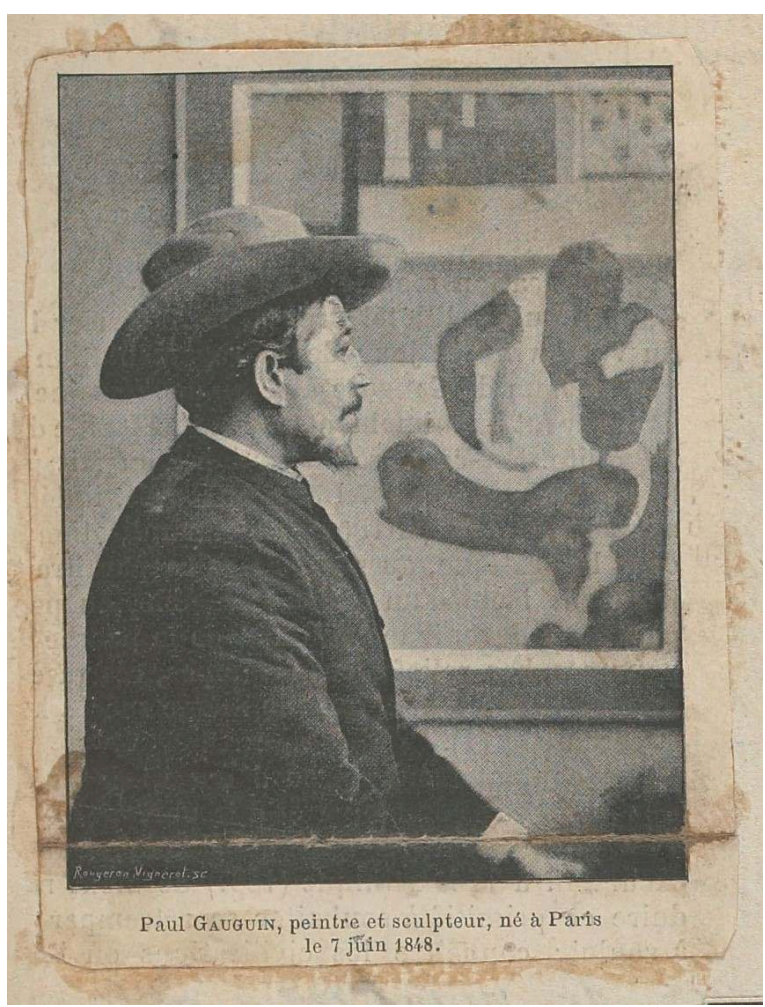

Gauguin in his Studio, c. 1893-4, from The Noa-Noa album, 31.5 × 23.2 cm, RF 7259-224-folio119 recto. Musée d'Orsay, Paris, France

(C) RMN-Grand Palais / Art Resource, NY

Photo: Hervé Lewandowski 
Figure 13

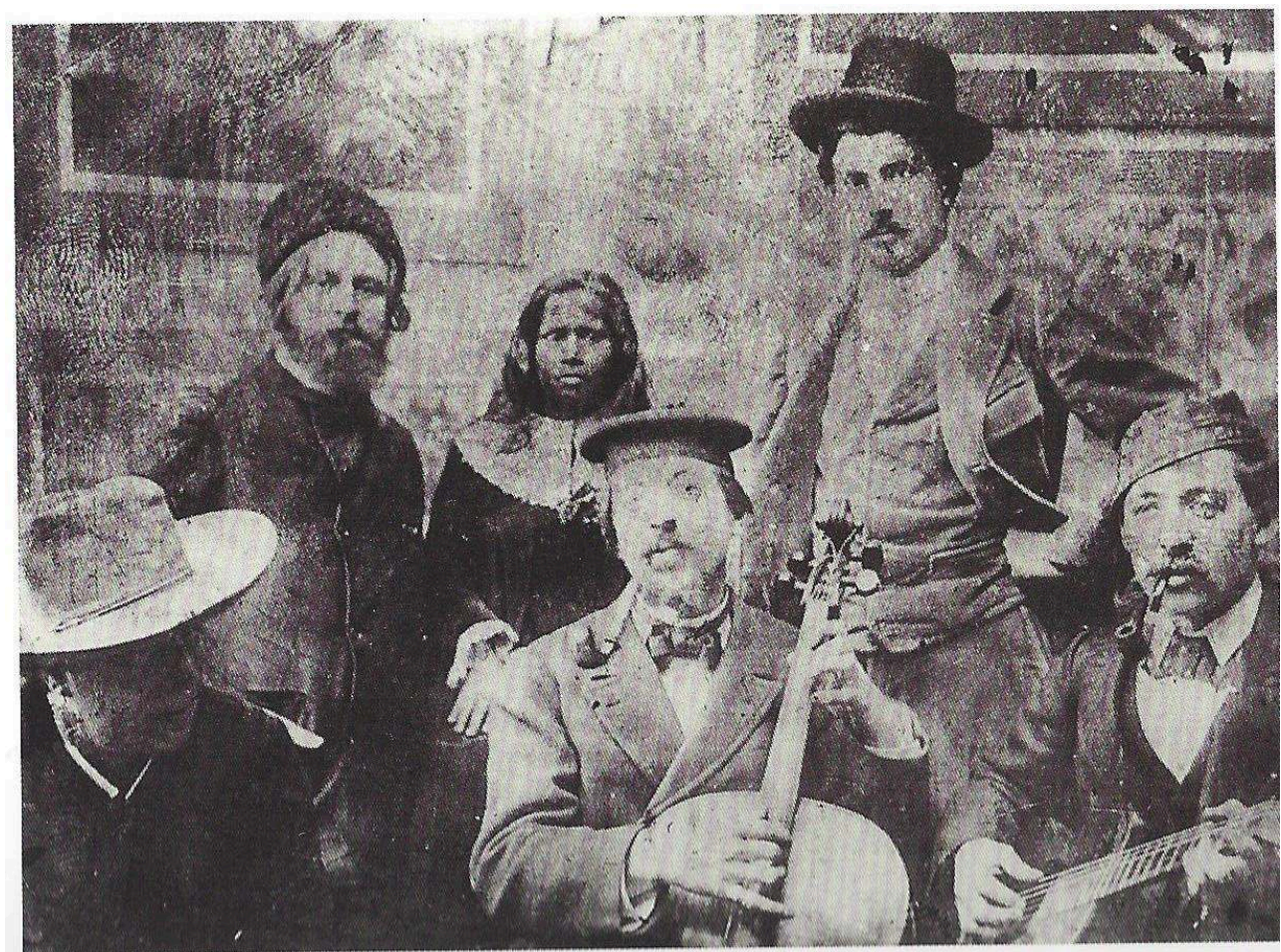

Gauguin's Studio at 6 rue Vercingétorix, 1893, Musée Gauguin, Papaeri. Possibly Gauguin at left.

Today, we would not recognize it as a cowboy hat. It does not resemble the hats worn by Buffalo Bill, which were specially ordered from Stetson with an extra-wide brim and were typically curled up on one or both sides (Snyder 5) (Figure 14). ${ }^{18}$ The crown is creased inward to make an easier grip. Thanks to Buffalo Bill's extraordinary selfpromotion and press coverage, his hat became instantly recognizable and takes a prominent place in the history of what we now call the cowboy hat. 
Figure 14

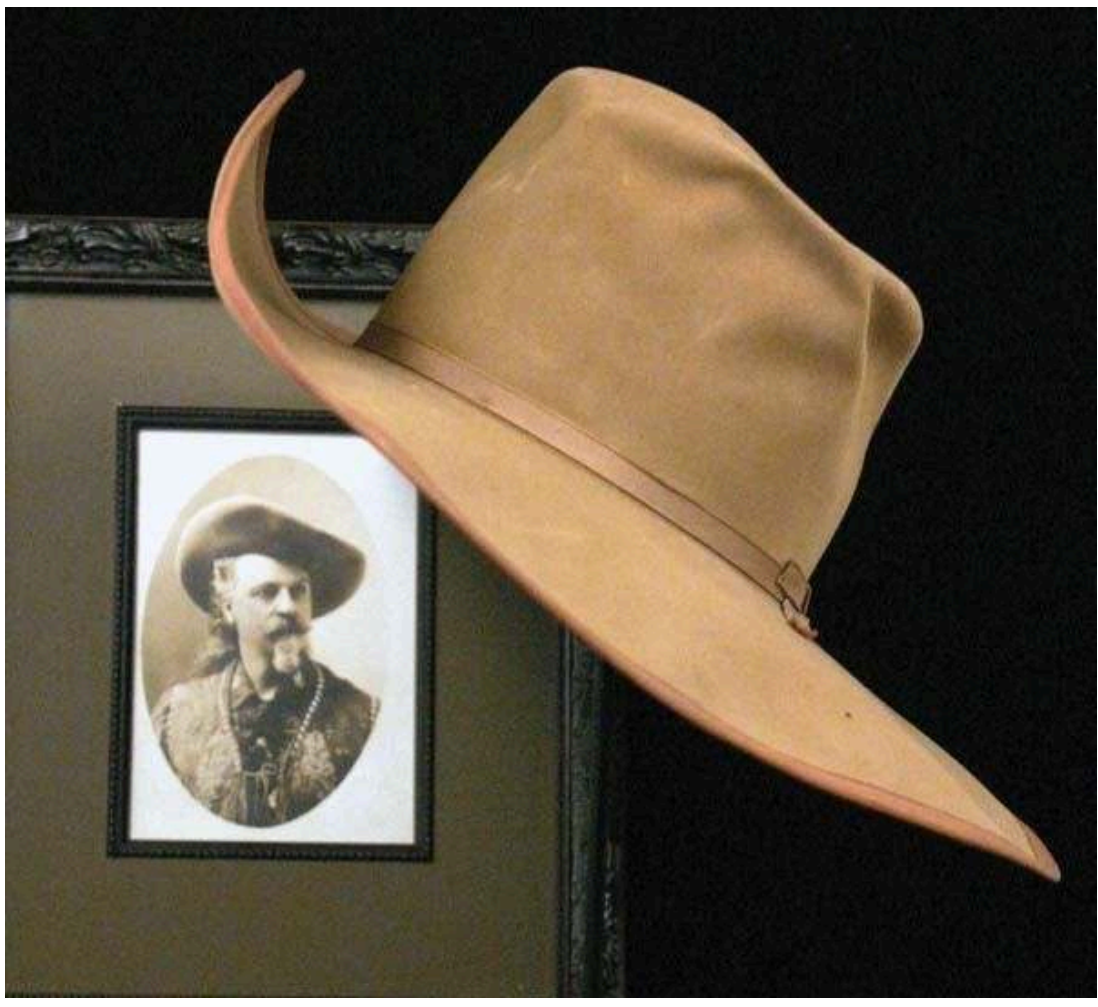

William F. Cody hat, worn by Buffalo Bill, c. 1911. https://www.liveauctioneers.com/item/ 1057179_120-w-f-cody-hat-worn-by-buffalo-bill

Figure 15

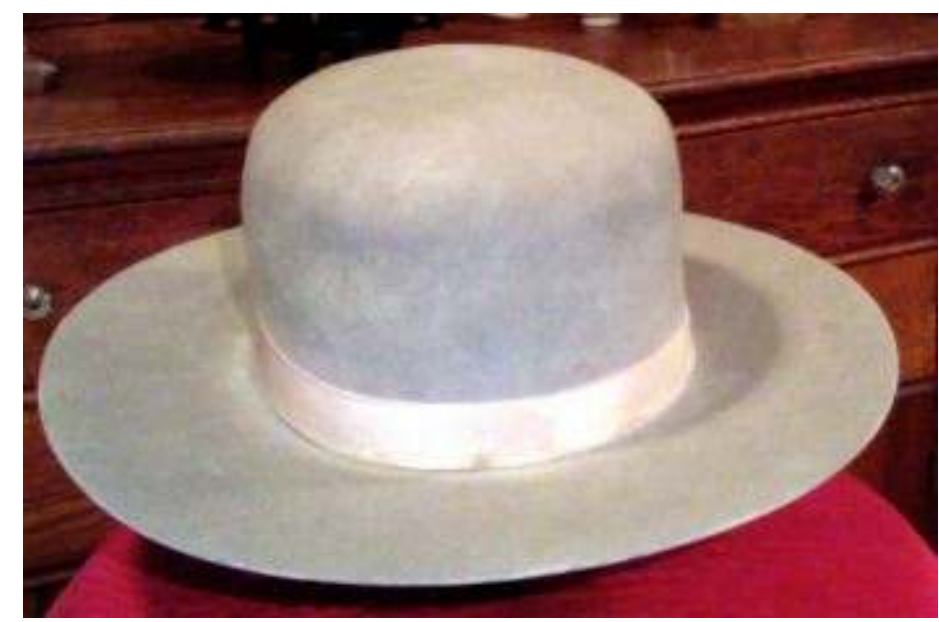

Stetson's "Boss of the Plains" felted hat, c. 1865, https://en.wikipedia.org/wiki/Boss_of_the_Plains\#/ media/File:1800sBoss_of_the_plains_5.jpg

But at the time, Gauguin's hat in this portrait did resemble the most commonly worn Stetson "cowboy" hat, which was invented in 1865 and called "Boss of the Plains" (Figure 15). This felted hat was considered perfect for the outdoor life-cool in summer, warm in winter, waterproof (it could be used to carry water if necessary), and easily shaped to suit the individual-it became the identifying badge of the western outdoorsman, especially someone who spent long days herding cattle. The cowboy 
performers in the Wild West show were usually shown with this kind of hat (Figure 16) rather than the one worn by Buffalo Bill, which has become the archetype. Gauguin, in this self-portrait, turns his head in a three-quarter view like Buffalo Bill's in the graphic (Figure 2) of one of the French programs used for the 1889 Paris venue.

Figure 16

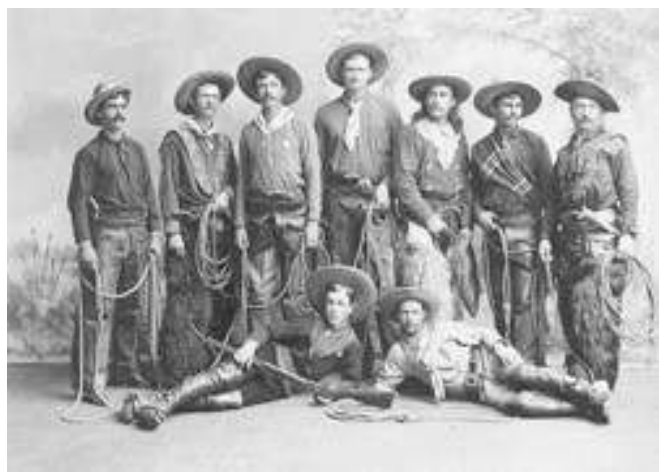

Cowboys from Buffalo Bill's Wild West, c. 1886-7, The William F. Cody Archive, Buffalo Bill Center of the West, Cody, Wyoming, USA, P.6.0086.

The iconic Buffalo Bill portrait was ubiquitous in Paris. Such photographs were printed in large quantities, autographed, and given to special visitors. As was typical of Buffalo Bill promotional materials, this image was based on a photograph. This particular photograph by F.W. Mora dated from several years earlier ("Buffalo Bill" Cody, ca. 1875, George Eastman House Collection, 1981:4350:0001), but Cody was so concerned about consistency in his brand that updated photographs were often taken in the same pose. Buffalo Bill's image also circulated in programs, which were widely available for sale, and in similar posters that were plastered around town. As one contemporary described, "The immense painted [sic] posters over the city [...] to advertise Buffalo Bill -his portraits pasted all in a row, many times larger than natural amuse the Parisians immensely" (Brooklyn Daily Eagle, May 30, 1889 3).

41 Self-Portrait with Hat was not exhibited at the time it was painted (1893-4), but went to Gauguin's friend William Molard, a French-Norwegian composer, whose portrait is painted on the reverse. It was posed at a pivotal time and has the haunting quality of an artist's private search for his true identity. Gauguin had returned to Paris with no intention of going back to Tahiti. But after only a few months, he again felt alienated in the city he still hoped to conquer. The re-appearance of the hat (the cause of such controversy when he arrived at Papeete in 1891) could serve as a recollection of the Buffalo Bill-style man who, like the famous "Scout," had chosen to wear the hat of infinite individualism when he first went to far-away Polynesia; and a signal that he would go back and continue to search for new artistic directions in the few ends of the earth imagined to remain.

\section{Gauguin, Tahiti, and American Commerce}

For Gauguin, the hat was one of two he immortalized in self-portraits in the year and a half he spent in Paris before returning to Tahiti in 1895. They both show Gauguin's fondness for masquerade and his self-image as a man who identified with exotic 
cultures. But the cowboy hat may have had a more practical significance in 1893-4 because Gauguin was seeking new audiences. Durand-Ruel was promoting him to his growing American clientele as an American, that is, as a Peruvian. Gauguin's exhibition of the Tahiti works at the Durand-Ruel gallery in Paris in November of 1893 was held immediately before a retrospective of Mary Cassatt, who was a major attraction for the American collectors of Impressionism. The earliest references to Gauguin, "this belated inheritor of the Incas," in American newspapers date to this time (New York Times, 1893 13). They reference his non-French background and world travels. Indeed, the Paris exhibition, it was felt, would be eagerly attended if Durand-Ruel would send it to New York (Ibid.). By the time of his death ten years later, he was erroneously considered to be "the son of a Breton sea Captain, and his mother was a Peruvian, with Indian blood in her veins" (New York Times, 1903 5). Gauguin's promoters used the mixture of the "white" and "red" skins, made familiar by Buffalo Bill, to put him into an American context for an American audience.

Gauguin was also conscious of American commerce from his experiences in French Polynesia during the last decade of his life. By the 1880s, American Pacific Coast merchants, particularly from San Francisco, began a high-speed route to Tahiti and the other Pacific islands such as Hawaii, which was annexed by the United States in 1893 (Gibbs 42). The largest American shipbuilder, Matthew Turner, led the way with his ships designed for speed, such as the schooner Papeete (1891), which could make the trip from San Francisco in seventeen days. American goods, including art supplies, were readily available on the island, and in a material sense Gauguin began to lead a more American lifestyle. When Gauguin moved from Tahiti to the Marquesas in 1901, he became good friends with the foremost merchant in the town of Atuona, the Californian Ben Varney. Gauguin lived on American exported goods, including food and clothing; and he built his house across from Varney's store in a traditional Polynesian style using Pacific northwest timber shipped from San Francisco (Le Bronnec 307-331; Boyle-Turner; Mathews 2001, 235-257). ${ }^{19}$ It is unlikely that Gauguin continued to wear the felt cowboy hat in such a hot, humid climate, but living in a town so strongly influenced by the merchandise of the American West, it would not have been out of place. To the day he died in 1903, he regaled his French, American, and Marquesan friends with tales of his triumphs in modern art and the role he played as its leader and scout.

Re-establishing Gauguin's Americanism, at the intersection of the French and Polynesian cultures he transformed in his symbolist art, adds dimension to our understanding of his use of exoticism and identity. The process of examining the cowboy hat also allows us to gain new perspective on Buffalo Bill, who not only provided Europeans with a tantalizing glimpse of American historical and social mythology through his performances, but who personally created a rich visual identity that could be appropriated by men and women, cowboys and Indians, and contemporary artists across a wide spectrum of styles. In considering Gauguin in light of his firsthand experience of Buffalo Bill in 1889 Paris, the sexually-complex cowboy "look" comes to the center of popular culture and highlights the multi-layered symbolism of the avant-garde cowboy-so meaningful to Gauguin and the construction of modern art as it came to be understood in the twentieth century. 


\section{BIBLIOGRAPHY}

BOSTON Daily Globe. "Fashion's Fads, A Cowboy Suit the Model for a Beauty.” August 4, 1889, p. 23. BOYLE-TURNER, Carolyn. Paul Gauguin \& the Marquesas. Pont Aven: Vagamondo, 2016.

BROOKLYN Daily Eagle. "Visit to the Fair." May 30, 1889, p. 3.

BURNS, Emily C. Transnational Frontiers, The American West in France. Norman: University of Oklahoma Press, 2018.

BUTLER, Judith. Gender Trouble, Feminism and the Subversion of Identity. New York: Routledge, 1990.

DICKEY, Susan K. "Work Clothes of American Cowboys: The Pictorial Record.” The Cowboy Way, An Exploration of History and Culture. Ed. Paul H. Carlson. Lubbock: Texas Tech University Press, 2006. Kindle Edition, 2013.

CHICAGO Tribune. "Personals." October 2, 1889, p. 4.

CHICAGO Daily Tribune. "Prince Bismarck at Homburg.” September 4, 1890, p. 5.

CHILDS, Elizabeth C. Vanishing Paradise, Art and Exoticism in Colonial Tahiti. Berkeley: University of California Press, 2013.

CHUNG, Yeon S. “The Monstrous and the Grotesque, Gauguin's Ceramic Sculpture.” Image [\&] Narrative, vol. 23, November 2008, www.imageandnarrative.be/inarchive/Timeandphotography/ shimchung.html. Accessed on Dec. 8, 2017.

CODY, William F. The Adventures of Buffalo Bill Cody. 1st ed. New York: Harper \& Brothers, 1904.

CODY, William F. The Life of Hon. William F. Cody, Known As Buffalo Bill, the Famous Hunter, Scout and Guide, An Autobiography. Hartford: Frank E. Bliss, 1879.

COOPER, John. "Oscar Wilde in America: a Selected Resource of Oscar Wilde's Visits to America." www.oscarwildeinamerica.org/sarony/sarony-photographs.html. Accessed on December 8, 2017.

DETROIT Free Press. “Men Are Known by their Hats.” June 8, 1883, p. 2.

DETROIT Free Press. "The Wild West, An Exciting and Satisfying Entertainment by Buffalo Bill and His Associates." June 6, 1885, p. 8.

DRUICK, Douglas and Peter ZEGERS. "Le kampong et la pagoda, Gauguin à la pagode, Gauguin à l'Exposition Universelle de 1889." Gauguin, actes du colloque Gauguin. Paris: Documentation française, 1991.

EISENMAN, Stephen. Gauguin's Skirt. London: Thames and Hudson, 1997.

FRIEDMAN, David M. Wilde in America, Oscar Wilde and the Invention of Modern Celebrity. New York: W.W. Norton \& Co., 2014.

GAUGUIN, Paul. “Notes sur l'art à L'Exposition Universelle.” Le Moderniste Illustré, July 5, 1889 (no. 11), p. 84, 86 and July 13, 1889 (no. 12), p. 90-91.

GAUGUIN, Paul. Lettres de Paul Gauguin à Emile Bernard, 1888-1891. Genève: Pierre. Cailler, 1954. GIBBS, Jim. West Coast Windjammers in Story and Pictures. Seattle: Superior Publishing Co., 1968. GILSON, Richard. The Cook Islands, 1820-1950. Wellington: Victoria University Press, 1980. 
GROOM, Gloria. Gauguin: Artist as Alchemist. Chicago: Art Institute of Chicago and Musée d'Orsay, 2017.

HARTRICK, Archibald S. A Painter's Pilgrimage through Fifty Years. Cambridge: Cambridge University Press, 1939.

JÉNOT, Paulin. "Le premier séjour de Gauguin à Tahiti d'après le manuscript Jénot." Gazette des Beaux-Arts, ser. 6, vol. 47, January-April 1956, p. 115-126.

JONNES, Jill. Eiffel's Tower, and the World's Fair Where Buffalo Bill Beguiled Paris, the Artists Quarreled, and Thomas Edison Became a Count. New York: Viking, 2009.

KASSON, Joy S. Buffalo Bill's Wild West, Celebrity, Memory, and Popular History. New York: Farrar, Straus and Giroux, 2000. Kindle Edition, 2015.

KELLY, Simon and Esther BELL. Degas, Impressionism, and the Paris Millinery Trade. San Francisco: Fine Arts Museums of San Francisco, 2017.

LE BRONNEC, Guillaume. "La Vie de Gauguin aux Iles Marquises.” Bulletin de la Societé des Études Océaniennes (March 1954) Gauguin, A Retrospective. Eds. Marla Prather and Charles Stuckey. New York: Hugh Lauter Levin, 1987, p. 307-331.

MALINGUE, Maurice. Paul Gauguin, Letters to His Wife and Friends. Boston: MFA Publications, 2003.

MATHEWS, Nancy M. Mary Cassatt and Her Circle, Selected Letters. New York: Abbeville Press, 1984.

MATHEWS, Nancy M. Paul Gauguin, An Erotic Life. New Haven: Yale University Press, 2001.

MAUFRA, Maxime. “Comment je connus Paul Gauguin.” Bulletin des amis des musées de Rennes, Summer 1978, p. 20-21.

MERLHÈS, Victor, ed. Correspondance de Paul Gauguin, documents, témoignages. Paris: Fondation Singer-Polignac, 1984.

MIRBEAU, Octave. "Paul Gauguin." L'Écho de Paris, February 16, 1890, p. 1.

MIRBEAU, Octave. “Paul Gauguin.” Le Figaro. February 18, 1891, p. 2.

MU-LIEPMANN, Véronique. “The Participation of the 'Établissement francais de l'Océanie' at the World's Fair in Paris in 1889." Gauguin, Polynesia. Ed. Suzanne Greub. Munich: Hirmer, 2011, p. 80-94.

NEW YORK Times. “Art in Paris.” Apr. 27, 1879, p. 2.

NEW YORK Times. "Buffalo Bill Gives a Party.” June 16, 1884, p. 5.

NEW YORK Times. “The Neo-Impressionists.” June 19, 1892, p. 19.

NEW YORK Times. “Art Notes.” December 10, 1893, p. 13.

NEW YORK Times. “Art Notes.” September 26, 1903, p. 5.

PETIT-RASSELLE, Roxane. "From the Literary Myth to the Lieu de Mémoire, Alexandre Dumas and French National Identity(ies)." The Black Musketeer, Reevaluating Alexandre Dumas within the Francophone World. Ed. Eric Martone. Newcastle on Tyne: Cambridge Scholars Publishing, 2011, p. 163-191.

REWALD, John, ed. Camille Pissarro, Letters to His Son Lucien. Santa Barbara: Peregrine Smith, Inc., 1981.

ROLLINS, Philip A. The Cowboy, his Characteristics, his Equipment, and his Part in the Development of the West. New York: Charles Scribner's Sons, 1922. 
RYDELL, Robert W. and Rob KROES. Buffalo Bill in Bologna, the Americanization of the World, 1869-1922. Chicago: University of Chicago Press, 2005.

SHACKELFORD, George T. M. and Claire FRÈCHES-THORY. Gauguin, Tahiti. Boston: MFA Publications, 2004.

SMITH, Jessica. "Oscar Wilde, Napoleon Sarony, 1882." www.hrc.utexas.edu/exhibitions/ permanent/windows/south/napoleon_sarony.html. Accessed on December 8, 2017.

SNYDER, Jeffrey B. Stetson Hats and the John B. Stetson Company: 1865-1970. Atglen, PA: Schiffer, 1997.

STASZAK, Jean-François. "Primitivism and the Other. History of Art and Cultural Geography." GeoJournal 60, n. 4, 2004, p. 353-364.

THOMSON, Belinda. "Gauguin Goes Public.” Paul Gauguin: Paris, 1889. Eds. Heather Lemonedes, Belinda Thomson, Agnieszka Juszczak. Cleveland: Cleveland Museum of Art and Van Gogh Museum, 2009, p. 29-73.

THOMSON, Belinda, ed. Gauguin, Maker of Myth. Princeton: Princeton University Press, 2010.

VARNEY, Dorothy J. California Gold. Cedar City: Jordan Publishing, 2010.

WALL, E. B. “E. Berry Wall on Dress.” Chicago Daily Tribune, July 14, 1889, p. 26.

WARREN, Louis S. Buffalo Bill's America, William Cody and the Wild West Show. New York: Penguin Random House, 2006.

WASHINGTON Post. "Buffalo Bill in Danger." June 3, 1889, p. 4.

WEISBERG, Gabriel. "Rosa Bonheur's Reception in England and America, The Popularization of a Legend and the Celebration of a Myth." Rosa Bonheur: All Nature's Children. New York: Dahesh Museum, 1998, p. 1-22.

WILDE, Oscar. Oscar Wilde On Dress. Ed. John Cooper. London: CSM Press, 2013. Kindle Edition. WILDENSTEIN, Daniel, Sylvie CRUSSARD and Martine HEUDRON, eds. Gauguin, A Savage in the Making/Catalogue Raisonné of the Paintings (1873-1888). Paris: Wildenstein Institute, 2002.

THE WILLIAM F. CODY Archive, Documenting the life and times of Buffalo Bill. codyarchive.org/ life/wfc.chronology.html. Accessed on December 8, 2017.

WILSON, Laurel E. “The Cowboy, Real and Imagined.” Dress, vol. 23, no. 1, July 2013, p. 3-15.

\section{NOTES}

1. "Disons le tout de suite, dès son débarquement Gauguin avait attiré le regard des indigènes; provoqué leur étonnement et aussi leurs lazzis, surtout ceux des femmes. Grand, droit, taillé en force, gardant, malgré sa curiosité déjà éveillée et soucieuse sans doute de ses futurs travaux, un grand air de profond dédain, il contrastait avec son voisin, le Capitaine, un peu plus petit, de figure ronde et bonasse et légèrement tassé sur lui-même. Tous deux devaient être à peu près du même âge, la quarantaine, mais ce qui retenait l'attention surtout sur Gauguin, c'était ses longs cheveux poivre et sel tombant en nappe sur ses épaules au-dessous d'un vaste chapeau de feutre brun à larges bords, à la cowboy" (Jénot 116). Unless otherwise noted, all translations are my own.

2. William F. Cody earned the nickname "Buffalo Bill" in the 1860 s as the primary supplier of buffalo meat for the workers of the Kansas Pacific Railroad (Cody 1904, viii). 
3. "Ma peinture soulève beaucoup de discussions et je dois le dire trouve un accueil assez favorable chez les Américains. C'est un espoir pour l'avenir." Paul Gauguin to Mette Gauguin, July 1886, in Merlhès $\mathrm{n}^{\circ} .107$, p. 133.

4. Notes manuscrites, RF 30569, 1, Fonds des dessins et miniatures, Réserve des petits albums, Album Gauguin Paul -5, Louvre, Département des Arts graphiques [“Album Walter"].

5. For an extensive bibliography of ethnography and representation, see Burns 177, fn 75-76.

6. For Gauguin's relationship with his Peruvian family and the South American colony in Paris, see Mathews, 2001 9-11, 19-22; and Wildenstein, Crussard and Heudron, Chronology, 559ff.

7. For a map of Gauguin's sea voyages to 1888, see Wildenstein, Crussard, and Heudron, 558.

8. "Sinon de bon et aimant je deviendrai une bête féroce" (Paul Gauguin to Mette Gauguin, April 1887, in Merlhès, $\left.\mathrm{n}^{\circ} .123,150\right)$.

9. Pissarro quotes Félix Bracquemond, "it was the art of a sailor, a little taken from everywhere" (Camille Pissarro to Lucien Pissarro, 23 January 1887, in Rewald 106).

10. It is important to note that Gauguin's claim of Inca heritage was a fabrication-his family arrived in Peru in the seventeenth century, but there was no history of intermarriage with the Incas or anyone else of Peruvian-Indian descent, see Mathews, 2001 6, fn. 3.

11. Vincent Van Gogh to Émile Bernard, 22 May 1888, http://vangoghletters.org/vg/letters/ let612/letter.html: "I've just read a book-not beautiful and not well written, by the way-on the Marquesas Islands, but very heart-rending in its description of the extermination of an entire tribe of natives-"

12. “De mémoire d'insulaire on n'avait jamais vu d'homme à longs cheveux dans l'île - mis à part les Chinois qui n'offraient pas le même aspect - aussi le jour même Gauguin fut-il surnommé taata vahine (homme femme), ce que les indigènes formulaient avec ironie, mais qui provoqua un mouvement de curiosité de femmes et d'enfants tel que je fus obligé de les faire chasser des abords de ma case. Gauguin, mis au courant sur l'heure, en rit d'abord, mais, au bout de quelques semaines, la chaleur aidant, il fit couper sa chevelure à la mode de tout le monde" (Jénot 116).

13. For more on the symbolism of hats in this era (mostly for women), see Kelly and Bell. For men's hats see ibid., 187-206.

14. For Sarony's photographs of Oscar Wilde, see Cooper, http://www.oscarwildeinamerica.org/ sarony/sarony-photographs.html and Jessica Smith, "Oscar Wilde, Napoleon Sarony, 1882." http://www.hrc.utexas.edu/exhibitions/permanent/windows/south/napoleon_sarony.html. For the amused response to Wilde in his "Buffalo Bill" hat, see Friedman 187-188.

15. "[Whistler] behaved like a fool here he and Oscar Wilde together [...]." (Mary Cassatt to Lois Cassatt, June 15 [1883], in Mathews 1984, 168).

16. My thanks to Emily Burns for pointing this out.

17. The hat was made of a felt "so fine as to roll up almost as would a handkerchief, a felt so costly that only ranchmen would pay its price [...]" (Rollins 306).

18. For more on cowboy dress, see Wilson 3-15; and Dickey, loc. 1857-2038.

19. For an interesting fictionalized account by a descendent of Ben Varney based on family accounts, see Varney, vol. II: Ben. 


\section{ABSTRACTS}

In this paper, I show how the French post-impressionist artist Paul Gauguin absorbed Buffalo Bill's dual cowboy and Indian mythologies from his visits to the Wild West show, which ran alongside the 1889 Paris international exposition. Gauguin brought to the Wild West in Neuilly his own recently-constructed identity as an American Indian (albeit Peruvian) and, in the years following-while in Brittany, Tahiti, and Paris-performed various aspects of the French interpretation of "Buffalo Bill" as applied to a pioneering modern artist. Gauguin's New World context was extensive, and included his Peruvian and other South American relatives, his art world audience of American artists and collectors, and, finally, his expatriation to the Pacific islands of Tahiti and the Marquesas. His adoption of the long hair and cowboy hat, made internationally famous by Buffalo Bill, gives us a key to understanding how he wove together the French and American cultural notions of primitivism, sexuality, leadership, and the avant-garde. And in turn it sheds new light on Buffalo Bill himself as we see him through the lens of the French avant-garde art community. In Gauguin's interpretation of both Buffalo Bill's gender performativity and of the avant-garde scout, we gain a new appreciation of Cody's daring embrace of androgyny and rejection of the narrowness of western civilization, all of which makes him more "modernist" than the twentieth-century cowboy mythology has previously led us to believe.

Cet article s'intéresse à l'influence du Wild West Show de Buffalo Bill sur l'artiste français postimpressionniste Paul Gauguin. Marqué par le Wild West Show qui se déroulait parallèlement à l'Exposition universelle de 1889 à Paris, Gauguin en assimila la double mythologie du cow-boy et de l'Indien. C'est lors d'une représentation du spectacle à Neuilly que Gauguin (bien que péruvien) revendique son identité d'Amérindien d'Amérique du Nord, et dans les années suivantes - en Bretagne, à Tahiti et à Paris - il adopte, et combine, divers aspects de la figure de " Buffalo Bill » telle que construite en France. Les liens de Gauguin avec le Nouveau Monde sont nombreux : sa famille péruvienne et sud-américaine, son audience internationale d'artistes et de collectionneurs américains sans oublier son expatriation dans les îles du Pacifique de Tahiti et des Marquises. Son adoption des cheveux longs et du chapeau de cow-boy, rendus célèbres dans le monde entier par Buffalo Bill, permet de mieux comprendre comment Gauguin a réussi à tisser ensemble les notions culturelles française et américaine du primitivisme, les questions de sexualité, son statut d'artiste avant-gardiste. En retour, «Gauguin l'Américain » jette un nouvel éclairage sur le personnage de Buffalo Bill, vu cette fois au prisme de la communauté artistique française d'avant-garde. L'interprétation par Gauguin de la performance genrée de Buffalo Bill et de la figure avant-gardiste de l'éclaireur (scout) permet de considérer à nouveaux frais l'adhésion audacieuse de Cody à l'androgynie et son rejet de l'étroitesse de la civilisation occidentale - ce qui le rend bien plus « moderniste » que ce que la mythologie entourant la figure du cow-boy issue au vingtième siècle nous a laissé croire. 


\section{INDEX}

Keywords: Gauguin, Buffalo Bill / William Cody, American Indians, 1889 Exposition Universelle, cowboy hat, post-impressionism, primitivism, avant-garde, primitivisme, androgyny, Paris, Peru, Tahiti, Polynesia, Marquesas, scout, Oscar Wilde, American art market

Mots-clés: Gauguin, Buffalo Bill / William Cody, Amérindiens, Exposition universelle de 1889, chapeau de cowboy, post-impressionnisme, primitivisme, avant-garde, androgynie, Paris, Pérou, Tahiti, Polynésie, Marquises, éclaireur, Oscar Wilde, marché de l'art américain

\section{AUTHOR}

NANCY MOWLL MATHEWS

nmathews@williams.edu 